\section{Ambulatory surgery update}

VER the past 20 years, the most dramatic change in the delivery of surgical care in the United States has been the shift from inpatient to outpatient and short-stay surgical care. Ambulatory surgery in the 1990s, with its demonstrated efforts at cost containment has been embraced by all segments of the American healthcare delivery system. Consequently, ambulatory surgery now accounts for approximately $65 \%$ of all surgical procedures performed, while in-patient procedures have dropped to a low of $35 \%$. Few healthcare professionals would dispute the fact that the steady growth of ambulatory surgery has significantly impacted the manner in which surgeons as well as anaesthesia providers practice. This lecture will highlight the newer developments in ambulatory anaesthesia, including opportunities for the perioperative physician in office-based anaesthesia, preoperative screening mechanisms, laboratory testing, choices of optimal anaestheric agents, and postoperative management.

\section{Office-based anaesthesia}

Technological advances and anaesthetic developments have allowed the number and complexity of outpatient surgical procedures performed each year to increase steadily, no longer limiting the practice site to hospitals. Currently, Ambulatory Surgery Centers (ASCs) and Office-Based Surgery account for approximately $12 \%$ and $8 \%$ respectively, of the market share in the USA. Projections are that ASCs and office-based procedures will increase to $17 \%$ and $14 \%$, respectively, by the year 2001 (Figure I). ${ }^{1}$ This growth has been primarily driven by financial incentives. Nevertheless, a high degree of surgeon and patient satisfaction continues to attract more procedures into this venue. Currently, common office-based procedures include plastic surgery, dermatology, oral surgery and gynaecological procedures (Figure 2). For the office-based procedure, notwithstanding the shift to a less intensive practice site, anaesthesia practice must be held to the same stringent standard of care as would apply in hospital-based facilities or ASCs. The role of the office anaesthetist goes beyond the discrete delivery of anaesthesia. ${ }^{1}$ Additional responsibilities may include determining the need for
Rebecca S. Twersky MD

accreditation of the facility as an anaesthetising site, confirming that the surgeon has appropriate credentials, assuring that the office is safely equipped, developing emergency protocols, appropriately screening patients, supervising patients' postanaesthesia recovery, and

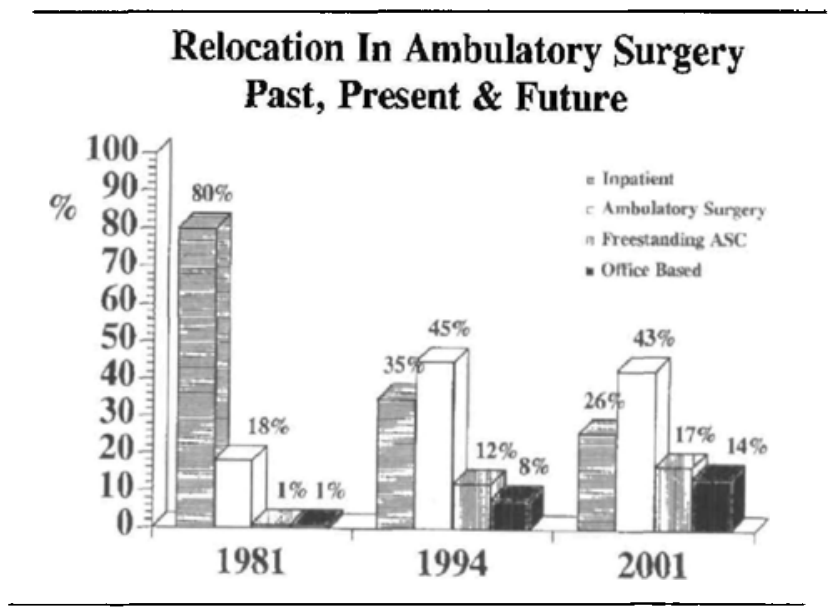

FIGURE 1

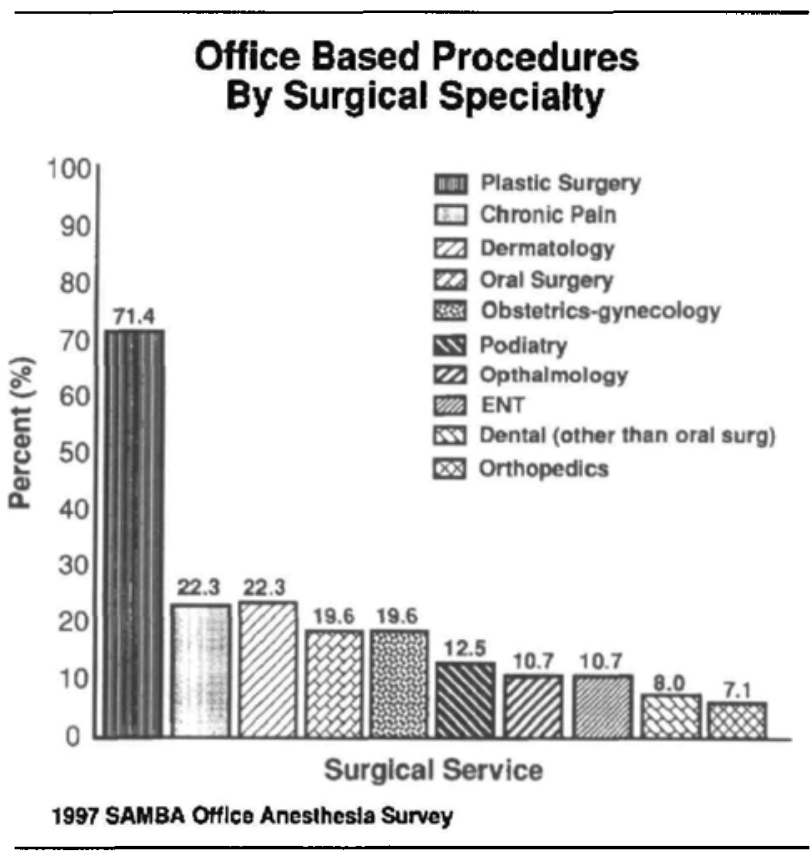

FIGURE 2

Ambulatory Surgery Unit, The Long Island College Hospital, Brooklyn, NY 1.1201; Phone: 718-780-I350; Fax: 718-780-1358;
E-mail: Twersky@pipeline.com 
quality improvement data management (Table I). The essentials of office anaesthesia must apply the basic standards and monitoring for anaesthesia as established by the American Society of Anesthesiologists (ASA). The office anaesthetist must ensure that the site is equipped to deliver positive pressure ventilation with an Ambubag, with an identifiable source of oxygen. Suction may be delivered via a portable or installed system; and all anaesthesia equipment should have a reliable back-up source and power in the event of equipment failure. Regardless of the chosen anaesthesia technique, emergency airway equipment, including a defibrillator is a must in the office practice site. While technicians and biomedical engineers are readily available in hospitalbased facilities and ASCs to oversee equipment failure and upkeep, such is not the case in the office setting. Therefore, it is crucial that service checks and equipment maintenance be rigorous, and strictly enforced. Furthermore, the anaesthetist must acquire familiarity with machine setup, as well as comfort in using them. In the office setting, the anaesthetist functions as both the pharmacist and pharmacy, and must ensure that a full compliment of medications is available, including those drugs necessary to resuscitate a patient in the event of cardiac or respiratory arrest; as well as dantrolene for the treatment of malignant hyperthermia. A narcotic license must be obtained through the Drug Enforcement Agency (DEA), if controlled substances are stored in the office.

Patient selection for the office-based setting will continue to evolve along with anaesthesia and surgical advances. The ASA physical status classification remains a significant element of patient selection; however, other elements are less clear. Age limits and morbidity associated with specific disease states (e.g., cardiovascular disease, asthma, morbid obesity), need to be better defined. As in the ASCs or hospitals, an effective method of evaluating patients for the office should be in place. A preoperative telephone interview conducted by the anaesthetist will aid in patient selection. As this practice venue increases in popularity, more quality assurance data will become available to guide in the selection of the appropriate patient for the officebased procedure.

\section{Preoperative anaesthesia clinics}

With the increasing proportion of patients scheduled for ambulatory or same-day surgery in all practice settings, a mechanism for smooth and seamless perioperative care is required. To date, preoperative anaesthesia clinics are the most comprehensive method available to meet this need. The anaesthetist, in his redefined role as perioperative medical specialist, is the best individual suited to conduct
TABLE I Office-based anaesthesia and surgery
Check-off list:
$\square$ Facility design
$\square$ Equipment and supplies
$\checkmark$ Patient flow
Ð Hospital transfer agreement
Ð Emergency set-up
$\square$ Credentialled and licensed MDs
$\square \mathrm{CQI} \&$ peer review

a medical assessment of the patient and plan the perioperative care. ${ }^{2}$ This cannot be delegated to the primary care physician. The advantages of establishing a preoperative anaesthesia clinic include a reduction in unnecessary laboratory tests and consultations, reduction in surgical cancellations and delays, with resultant increase in surgeon provider and patient satisfaction. ${ }^{3}$ The key to the success of a pre-anaesthesia clinic lies in the adequacy of its staffing. The anaesthetist, as Medical Director, conducts a comprehensive evaluation in collaboration with either anaesthesia residents, physician assistants, nursing practitioners, or perioperative nurses. Other key personnel include nursing educators, who are responsible for the key portions of preoperative education, laboratory staff, Radiology and ancillary services, admitting clerks, medical records personnel and office manager. The ideal preoperative clinic occurs where all the various elements of preoperative assessments are scheduled during a single visit. The concept of "one-stop shopping" has been popularised as promoting streamlined and patient-focused care. The goal is a preoperative anaesthesia clinic with the capability to conduct the requisite evaluation in a single visit, at least for the majority of patients. Included should be registration areas, integration with the facility's computer system, examination and assessment rooms where vital signs, patient interviews and examination, phlebotomy and ECGs can be conducted. Additionally, Radiology services should be integrated, or available nearby. Audiovisual set-up or an area for the display of patient education literature may enhance preoperative teaching. Depending on the severity of the patient's medical disease and planned surgical procedure, alternative options may be considered for adaptation to the specific surgical facility (Figure 3). One such alternative is the health questionnaire completed in the surgeon's office or the primary care physician's office, with review of data by the anaesthesia staff prior to the administration of anaesthesia. However, the success of this option is dependent on a line of clear communication among anaesthetists, surgeons and primary care physicians as to what constitutes a "stable" patient. Due to the lack of uniformity that exists in the way colleague physicians evaluate patients for "clearance," a 


\section{Algorithm for Preanaesthesia Evaluation}

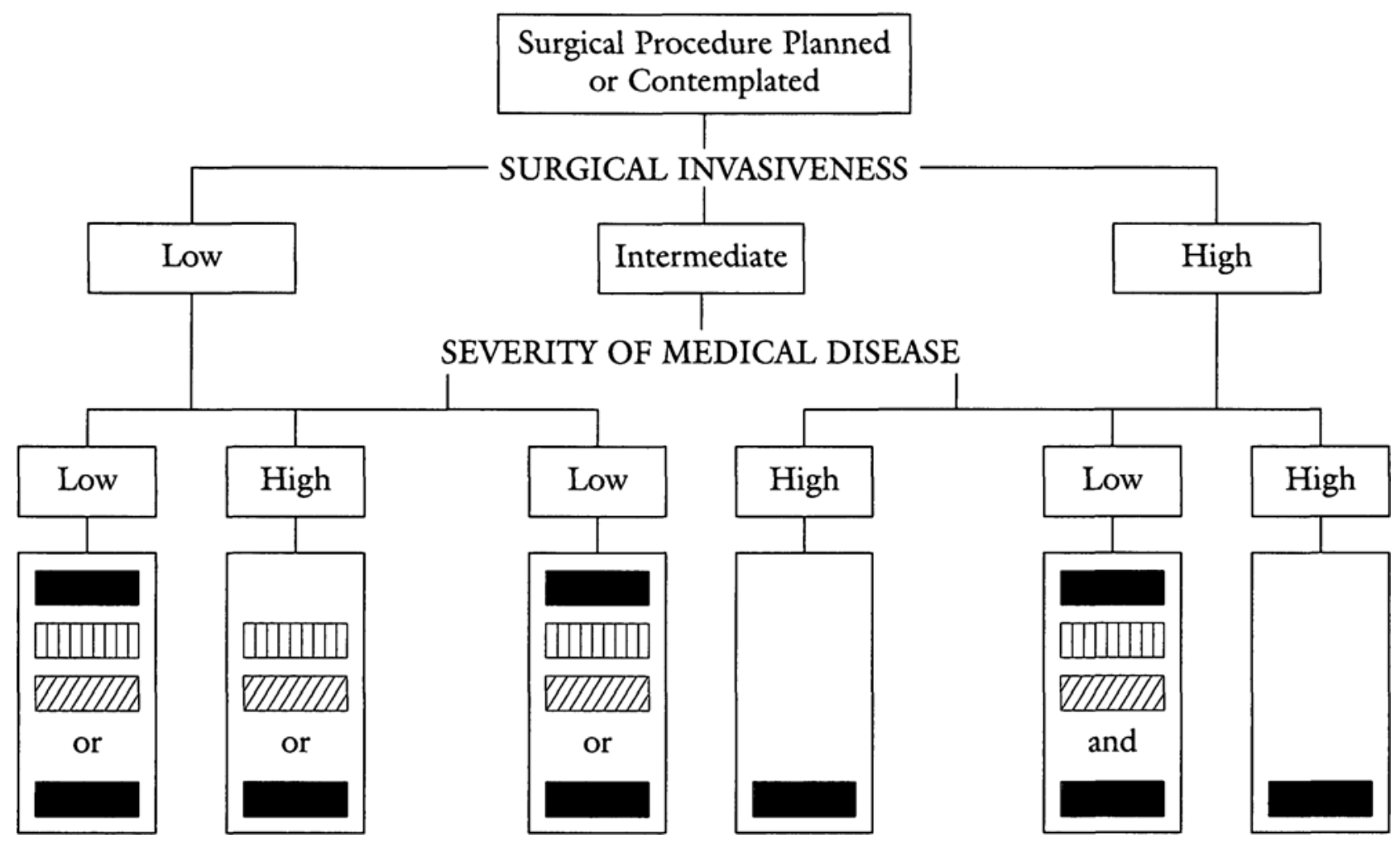

FIGURE 3 Algorithm for Preanaesthesia Evaluation

Model A: Patient info from surgeon; Anaesthesia staff review of data prior to or on Day of Surgery (D.O.S.)

IIII) Model B: Patient info from the Primary Care Physician (PCP); Anaesthesia staff review prior to or on D.O.S.

एIII] Model C: Patient info from either PCP or surgeon; Telephone screening by anaesthesia staff prior to D.O.S.

Model D: Patient info from either the PCP or surgeon; Evaluation by anaesthesia staff in an anaesthesia clinic prior to the D.O.S.

standardised form distributed for use can resolve this issue. However, it is important to note that the evaluation is not for clearing patients, but rather for assessing whether the patients are in optimal condition for surgery. The value of preanaesthesia clinics is highlighted when "problem" patients are identified early on in the process; and the final medical decision-making is reserved for the anaesthetist. ${ }^{4}$ For the presumably healthier patients, presurgical telephone interview conducted by a member of an anaesthesia-directed team may help to initiate the pre-anaesthesia evaluation, identify inappropriate candidates, and dispel misinformation regarding preoperative instructions. Computerised health assessments and patient use of the Internet will prove valuable in further streamlining. Clinical and administrative efficiencies, as well as the visibility of the anaesthetist, are major factors for promoting the preanaesthesia clinics. Above all, preoperative screening clinics must be tailored to the particular practice, influ- enced by mechanisms in place at the facility and the complexity of the patient population.

Unnecessary laboratory testing has been a contributing factor in excessive healthcare costs. Multiple studies have concluded that screening laboratory tests show unexpected abnormalities very infrequently and rarely lead to changes in management that improve outcome. ${ }^{5}$ For example, a meta analysis of studies of preoperative chest $x$-rays in the absence of specific indications, showed that false positive results leading to invasive procedures and associated morbidity were more frequent that the discovery of any new findings leading to a change in management. ${ }^{6}$ There is little reason to perform screening tests in asymptomatic, low risk patients. Appropriate preoperative testing should be performed only if indicated by the medical history or physical examination, or its influence on perioperative care (Table II). 


\section{Patient Selection}

Notwithstanding the most comprehensive screening clinic or alternative methods of evaluation, medically challenging patients will continue to be scheduled for elective outpatient surgery. Key questions that should be asked when deciding whether or not a patient is appropriate for this setting include: 1) what is the extent of the patient's disease, 2) What is the patient's functional status? 3) Is the patient medically optimised? 4) Could the patient be managed in a free-standing or hospital-integrated ambulatory surgical facility? 5) What are the risks of sending this patient home the same day? 6) Would the patient be best managed as an inpatient? At a minimum, these questions should be addressed, with appropriate dialogue among the surgeon, anaesthetist and the primary care physician. Surgery and anaesthesia for such a patient may proceed only after there has been resolution of the medical issues, and it has been determined that the patient is medically stable, and the discharge environment is suitable.

Despite technological advances and anaesthesia developments, there are still some types of patients who pose a risk for ambulatory surgery, and for whom alternative settings should be sought (Table III). Included in this category are unstable ASA 3 and 4 patients, brittle diabetics, active substance/alcohol abusers, poorly controlled seisure disorders, the morbidly obese patient with coexisting disease, and the malignant hyperthermia-susceptible patient as a relative risk. Several risk factors have been associated with an increased incidence of cardiac and respiratory problems in the perioperative ambulatory period, ${ }^{7}$ and therefore, patients in this risk category should be carefully evaluated as to their outpatient candidacy. Most children are healthy, and require minimal preoperative preparation. Paediatric preoperative evaluation should include an appropriate history and physical (including medications), the determination of the patient's condition for surgery, and recommendations as indicated (e.g., SBE prophylaxis, steroid treatment). Those with significant coexisting disease may benefit from outpatient surgery because of reduced parental separation and shorter exposure to nosocomial infections. Nonetheless, as with the adult population, there are still selected inappropriate pediatric outpatients, including those with a history of sleep apnea, sickle cell disease, and malignant hyperthermia (relative risk). At what age can a paediatric patient have ambulatory surgery? Healthy, full-term infants at 44 weeks may have elective ambulatory surgery; premature infants, however, are inappropriate. Risk of postoperative apnea in ex-preemies has excluded the ex-preemie $-<44$-wk postconceptual age (PCA), and the ex-preemie - $>$ 60-wk PCA with ongoing cardiopulmonary symptoms (Table IV)..$^{8}$ Healthy, full-term infants at 44 weeks may have elective ambulatory surgery.
TABLE II Pre-anaesthesia testing recommendations for asymptomatic healthy individuals

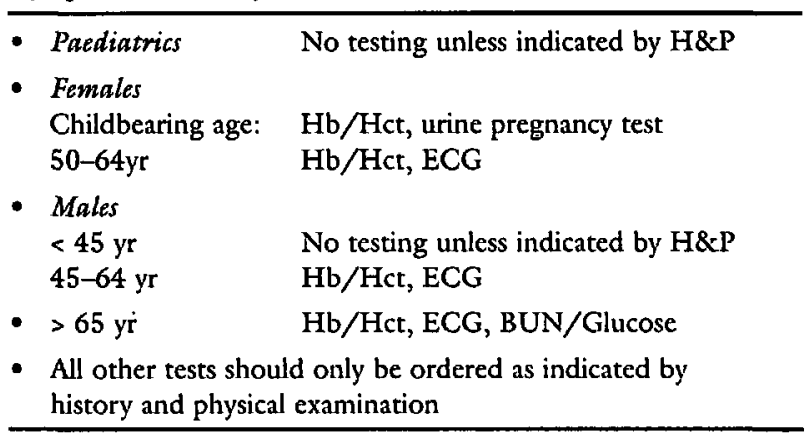

TABLE III Inappropriate adult outpatients

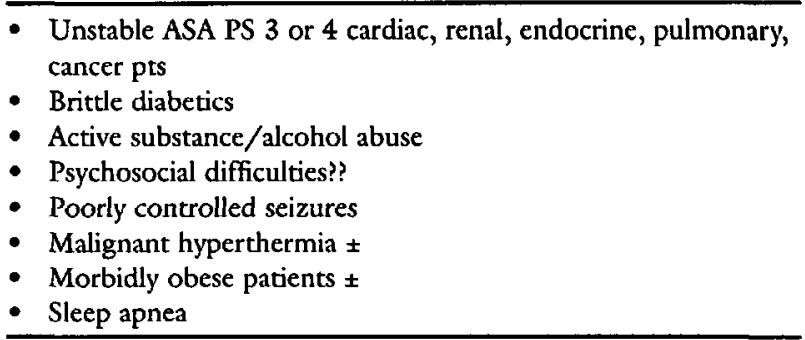

TABLE IV Ex-preemies risk of postoperative apnea

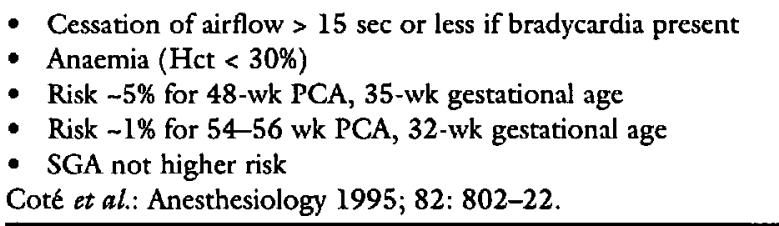

\section{New outpatient anaesthetics}

What is the "ideal outpatient anaesthetic"? The ideal outpatient anaesthetic should provide a safe, simple technique, with a quick start (onset of action), rapid stop (offset of effects), minimal postoperative side effects, with residual analgesia during the early post-operative period. The development of intravenous (c.g., remifentanil, propofol), and inhalational (e.g., desflurane, sevoflurane) anaesthetic agents with demonstrated properties of quick onset and rapid recovery profiles desirable in the ambulatory surgery setting, has had positive impact on ambulatory anaesthesia practice. Since its development in the late $1980 \mathrm{~s}$, propofol has retained its central role as a principal agent for the induction and maintenance of general anaesthesia, and sedation in the ambulatory setting. By virtue of its unique recovery profile compared with other $i v$ anaesthetics, propofol is considered to be the induction and maintenance sedative-hypnotic agent of choice for ambulatory anaesthesia.9 Propofol's extremely rapid metabolic clearance properties facilitates 
the patient's rapid emergence from anaesthesia and return to a clearheaded state.

Remifentanil is one of the newest intravenous anaesthetic agents. It is an ultra short-acting potent opioid, with an extremely rapid onset of action (blood levels are achieved within 2-3 minutes of onset). Hydrolysed by plasma tissue esterases, the beta halflife is approximately 6-10 min and by-products are clinically inactive. ${ }^{11,12}$ Therefore, the drug can be infused for optimal maintenance of anaesthesia without fear of blood accumulation. However, a consequence of this property is that patients may experience pain sooner and transitional analgesia (e.g., ketorolac, long-acting local anaesthetic) must be initiated in the OR to provide for analgesia in the early postoperative period. ${ }^{12} \mathrm{~A}$ benefit of the requirement for transitional analgesia is that it forces the anaesthetist to focus on the postoperative analgesia plan while in the OR. The use of remifentanil in the ambulatory setting is especially beneficial in patients with cardiac diseases requiring intensive opioid analgesia without residual narcosis. Remifentanil may add value with a reported lower incidence of opioid induced emesis. ${ }^{13}$

Desflurane and sevoflurane are newer inhalational anaesthetics, marketed in the United States in 1993, and 1995, respectively. Desflurane, at room temperature, is a clear non-flammable liquid with a strong odour. It is a fluorinated methyl-ethyl ether, identical in structure to isoflurane except for the substitution of a fluorine for the chlorine in the alpha-ethyl carbon. It is the least soluble, potent inhalational agent, with a blood-gas partition coefficient of 0.42 , and a MAC of $6.0 \pm 0.09$ in adults aged 30 to $60 \mathrm{yr}$. Desflurane's high vapour pressure requires the special Tec 6 vaporiser to provide adequate temperature control and accuracy of flow in all settings. Unfortunately, design problems have plagued the Tec 6 system since its creation and resulted in a substantial delay in the initial release of desflurane by after FDA approval and, more recently, a massive vaporiser recall due to inaccurate output at elevated desflurane concentrations with high gas flow. The problem in vaporiser calibration now appears to have been resolved.

Recently, the role of desflurane in the generation of carbon monoxide (CO), from carbon dioxide absorbers has been studied. Desflurane has been shown to produce up to $2,000 \mathrm{ppm} \mathrm{CO}$, and was found to produce 15 times as much $\mathrm{CO}$ as isoflurane in the presence of high temperature $\left(45^{\circ} \mathrm{C}\right)$ and dry carbon dioxide absorbent (particularly barium hydroxide absorbents). ${ }^{14}$ United States Food and Drug Administration (USFDA) Center for Disease Control has made the following recommendations regarding $\mathrm{CO}$ poisoning during anaes- thesia: 1) all soda lime that has been dormant in the anaesthetic machine for more than $24 \mathrm{hr}$ should be changed and dated and, 2) the anaesthesia machine should be flushed continuously with $100 \% \mathrm{O}_{2}$ for at least one minute before the first case of the day.

Cardiovascular effects of desflurane are similar to those of isoflurane. Transient sympathetic nervous system activation, resulting in hypertension and tachycardia occur in relation to concentration and rate of rise of desflurane. Intravenous opioids, propofol or clonidine can blunt this response. Desflurane should be used with caution for induction of general anaesthesia as high inspired concentrations have been shown to cause airway irritation with resultant coughing, excessive salivation, laryngospasm, and breath-holding. Therefore, desflurane is far more suitable for maintenance of anaesthesia in the ambulatory setting. Recent studies have shown that desflurane permits a faster emergence from anaesthesia than propofol, when both were used for induction of anaesthesia. However, later recovery and discharge times were similar for both agents. ${ }^{15}$

Sevoflurane, at room temperature, is a clear nonflammable liquid with little or no pungent odour. It is a methyl-isopropyl ether with a MAC of $2.93 \%$ in adults, and a blood-gas partition coefficient of $0.6-0.7$, approaching that of $\mathrm{N}_{2} \mathrm{O}$, making it well suited for ambulatory anaesthesia. Cardiovascular changes appear to be less with sevoflurane, with no apparent sympathetic nervous system activation. Sevoflurane appears to be unstable under both in vitro and in vivo conditions. The in vitro degradation involves a reaction of sevoflurane with carbon dioxide absorbent to various compounds called compounds A, B, C, and D. Although under certain clinical conditions all these compounds can be formed, the amounts of Compounds B, C, and D appear to be insignificant $(<0.5 \mathrm{ppm})$ and are usually generated only when the absorbent temperature is higher (up to $46^{\circ} \mathrm{C}$ ). Compound $\mathrm{A}$ has generated the greatest concern because of its renal toxicity in various animal models. The toxicity of Compound $\mathrm{A}$ in rats is well documented and primarily involves corticomedullary toxicity (around 100-300 ppm), inducing renal tubular acidosis. However, in spite of extensive clinical testing, several studies have failed to demonstrate any hepatic or renal dysfunction in humans, even at very low fresh gas flows. ${ }^{16,17}$ When administered according to the guidelines in the package insert, the likelihood of long-term toxicity in humans from sevoflurane exposure appears to be extremely low, even when sevoflurane is administered for prolonged anaesthesia.

Single breath induction with sevoflurane permits rapid onset and provides smooth awakening, and 
emergence. ${ }^{18}$ In comparison with isoflurane, emergence, awakening and extubation and the ability to follow commands is at least as rapid. ${ }^{19}$ Several studies in children have shown that after inhalational induction with either sevoflurane, halothane, or desflurane, sevoflurane allowed more rapid inductions ${ }^{20}$ and may allow more rapid or at least equivalent emergence. Compared with propofol, sevoflurane showed more rapid emergence and orientation. ${ }^{21,22}$

In summary, both sevoflurane and desflurane provide a greater degree of control of anaesthetic depth and a more rapid immediate recovery from anaesthesia than is currently available with other inhaled agents. ${ }^{23}$

\section{Fast-tracking recovery}

When compared with other hypnotics and inhalational agents, sevoflurane, desflurane, propofol and remifentanil provide superior immediate recovery profiles; however, these differences do not appear to persist into the later recovery period. There appears to be no significant difference between desflurane, sevoflurane, propofol and remifentanil with respect to home-readiness or discharge time from the ambulatory facility. Therefore, in order to demonstrate the potential advantages of these newer and more expensive compounds, modifications are required in the PACU and Phase II discharge criteria. If ambulatory patients are awake and oriented in the OR, transfer of these patients directly to the stepdown unit, and bypassing the PACU (called "fast tracking"), will result in earlier discharge time. Criteria for "fast tracking" recovery include a patient who is awake and oriented on the OR table, with stable vital signs, minimal pain or bleeding, minimal nausea/vomiting, complete reversal of neuromuscular blocking agents, and oxygen saturation $\geq 94 \%$ breathing room air or resumption of baseline level. ${ }^{24}$ Under these conditions, the patient may bypass PACU and be transferred directly to step-down recovery with appropriate care in that facility. In order to truly achieve "fast-tracking," a more effective method of titration of anaesthetics agents to determine the necessary amount for anaesthesia is crucial. This need has been filled by the BIS (Bispectral Array) EEG monitor, manufactured by Aspect. Unlike other EEG monitors designed for the operating room, the BIS monitor displays a continuous parameter for evaluation of anaesthesia depth, the BIS or bispectral index. The benefits of bispectral index include the ability to measure hypnotic state with strong correlation of hypnotic drugs levels, the capability for more precise titration of anaesthetic agents, determination of neurological readiness for extubation and ability to track patient arousal. Incorporation of the BIS monitor for both general and MAC anaesthesia cases has resulted in significant decrease in the amount of anaesthetic administered. ${ }^{25}$ The use of the BIS monitor to determine the dose of propofol or concentration of inhalation agents, elimination of premedicant and opiates will translate into the benefits of reduction of nausea/vomiting, early ambulation, increased patient satisfaction, and rapid recovery and discharge from the ambulatory setting. ${ }^{26}$ The patients may be safely discharged home after vital signs have stabilised, the patient can ambulate without dizziness, there is minimal pain, nausea, and vomiting, surgical bleeding and a responsible escort can accompany the patient home. ${ }^{27}$

\section{Postoperative pain and emesis}

Two of the most common problems seen in the ambulatory surgery patient are pain, and nausea and vomiting. Opioids (e.g., fentanyl, demerol, morphine) are still the most common and effective method of treating acute moderate to severe postoperative pain. Because of the undesirable emetic symptoms after opioid treatment, use of nonsteroidal antiinflammatory agents (NSAIDs), or long-acting local anaesthetics should be considered as part of multimodal analgesic treatment. The advantages of NSAIDs over opioids are the lack of respiratory depression, gastrointestinal immotility, and longer duration of action. Caution should be exercised in patients at risk for bleeding, renal impairment, or bronchospastic disease. For mild to moderate postoperative pain, oral medication usually a combination of opioids and nonopioids (e.g., acetaminophen with codeine, percocet) has proved to be effective (Table V). ${ }^{27}$

Perhaps, as troubling as postoperative pain is, the occurrence of postoperative nausea and vomiting (PONV) is worse. For the most susceptible patients (patients with previous history of nausea/vomiting, motion sickness, women in the luteal phase of the menstrual cycle), prophylactic antiemetic therapy should be considered. The type of surgical procedure also influences PONV; specifically, strabismus repair, laparoscopy, middle ear surgery and orchiopexy are all associated with relatively high incidence of postoperative vomiting. A number of anaesthetic agents, including nitrous oxide, have been associated with precipitating PONV; however, more recent studies have been unable to find such a causal relationship. Despite significant improvement in the pharmacological management of PONV, single drug treatment is not completely effective. However, a multimodal approach has prove successful, including a $92 \%$ complete treatment achieved with a combination of droperidol and ondansetron. ${ }^{28}$ (Table VI) Serotonin antagonists, the newer group of antiemetic compounds (e.g., ondansetron, granisetron, dolasetron), have 
TABLE V Commonly used analgesic drugs and dosages

\begin{tabular}{llll}
\hline Dritg & Route & Dose & $\begin{array}{l}\text { Duration } \\
\text { of action (br) }\end{array}$ \\
\hline Acetaminophen & pr/po & $25-40 \mathrm{mg} \cdot \mathrm{kg}^{-1}$ & $4-6$ \\
Ketorolac & im $/$ ? iv & $1 \mathrm{mg} \cdot \mathrm{kg}^{-1}(\mathrm{Max} 30 \mathrm{mg})$ & $6-8$ \\
& po & $1 \mathrm{mg} \cdot \mathrm{kg}^{-1}(\mathrm{Max} 10 \mathrm{mg})$ & $4-6$ \\
Ibuprofen & po & $5 \mathrm{mg} \cdot \mathrm{kg}^{-1}$ & $6-8$ \\
Codeine & po & $0.5-1 \mathrm{mg} \cdot \mathrm{kg}^{-1}$ & $4-6$ \\
Naproxen & po & $10 \mathrm{mg} \cdot \mathrm{kg}^{-1}$ & $6-8$ \\
Fentanyl & iv & $1-2 \mu \mathrm{g}^{-1}$ & $0.5-1$ \\
Meperidine & iv $/ \mathrm{im}$ & $0.5-1 \mathrm{mg} \cdot \mathrm{kg}^{-1}$ & $2-4$ \\
Morphine & iv & $0.05-0.1 \mathrm{mg}^{\mathrm{k}} \mathrm{kg}^{-1}$ & $2-4$ \\
\hline
\end{tabular}

TABLE VI Effective PONV treatments in ASU

\begin{tabular}{ll}
\hline - Droperidol & $0.625-1.25 \mathrm{mg}$ iv \\
- Ondansetron & $4 \mathrm{mg}$ iv \\
- Ondansetron \& Droperidol & $4 \mathrm{mg} / 1.25 \mathrm{mg}$ iv \\
+ Dexamethasone & $150 \mathrm{\mu g} \cdot \mathrm{kg}^{-1}$, up to $8 \mathrm{mg}$ \\
- ?Propofol & $10 \mathrm{mg}$ \\
- Newer $5 \mathrm{HT}_{3}$ antagonists & \\
\hline
\end{tabular}

proven effective in the management of PONV but the cost is very significant. ${ }^{29-31}$ Therefore, routine prophylactic use in the current climate of cost containment is prohibitive. Watcha et al..$^{32}$ in a cost effectiveness analysis of antiemetic therapy in ambulatory surgery, concluded that prophylactic use of droperidol was more favourable than ondansetron.

\section{Conclusion}

Ambulatory surgery today represents a new challenge for the anaesthetist as the focus has shifted to the bottom line: cost containment and competitive quality care. The perioperative anaesthetist can apply much of the lessons learned in hospital-based ambulatory surgery and apply them to all practice settings in order to maintain high quality anaesthesia with favourable outcomes.

\section{References}

1 Twersky RS, Koch M. "Practice options: considerations in setting up an office-based anesthesia practice. ASA Newsletter 1997; 61: 30-2.

2 Wiklund RA, Rosenbaum SH. Medical Progress. Anesthesiology ( First of Two Parts). N Eng J Med 1997; 337: 1132-41.

3 Fischer SP. Development and effectiveness of an anesthesia preoperative evaluation clinic in a teaching hospital. Anesthesiology 1996; 85: 196-206.

4 Twersky RS. Patient and procedure selection for adult ambulatory surgery. LARS Refresher Course Lecture, 1998; Orlando, Florida.
5 Perez A, Plannel J, Bacardaz $C$, et al. Value of routine preoperative test: a multicentre study in four general hospitals. Br J Anaesth 1995; 74: 250-6.

6 Archer $C$, Levy $A R, M c$ Gregor $M$. Value of routine preoperative chest $\mathrm{x}$-rays: a meta analysis. Can J Anaesth 1993; 40: 1022-7.

7 Chung F, Mezei G, Tong D. Preexisting medical conditions as predictors of adverse events in ambulatory surgery. Anesthesiology 1997; 87: A27.

8 Cote CJ, Zaslavsky A, Downes JJ, et al. Postoperative apnea in former preterm infants after inguinal herniorrhaphy. Anesthesiology 1995; 82: 809-22.

9 Smith I, White PF, Nathanson $M$, Gouldson $R$. Propofol: an update on its clinical use. Anesthesiology 1994; 81: 1005-43.

10 Burkle $H$, Dunbar S, Van Aken H. Remifentanil: a novel, short-acting u-opioid. Anesth Analg 1996; 83: 646-5l.

11 Gold MI, Watkins DW, Sung YF, et al. Remifentanil versus remifentanil/midazolam for ambulatory surgery during monitored anesthesia care. Anesthesiology 1997; 87: 51-7.

12 Philip BK, Scuderi PE, Chung F, et al. Remifentanil compared with alfentanil for ambulatory surgery using intravenous anesthesia. Anesth Analg 1997; 84: 515-21.

13 Twersky RS, Thompson D, Warner DS, et al. The incidence of nausea following a remifentanil-based anesthetic regimen. Anesth Analg 1998; 518.

14 Baxter PJ, Kharasch ED. Rehydration of desiccated baralyme prevents carbon monoxide formation from desflurane in an anesthesia machine. Anesthesiology 1997; 86: 1061-5.

15 Dexter F, Tinker JH. Comparisons between desflurane and isoflurane or propofol on time to following commands and time to discharge. Anesthesiology 1995; 83: 77-82.

16 Bito $H$, Ikeuchi $\Upsilon$, Ikeda $K$. Effects of low-flow sevoflurane anesthesia on renal function. Anesthesiology 1997; 86: 1231-7.

17 Kharasch ED, Frink EJ, Zager $R$, et al. Assessment of low-flow sevoflurane and isoflurane effects on renal function using sensitive markers of tubular toxicity. Anesthesiology 1997; 86: 1238-53.

18 Sloan MH, Conrad PF, Karsunky Pk, Gross JB. Sevoflurane: induction and recovery characteristics with single-breath inhaled inductions of anesthesia. Anesth Analg 1996; 82: 528-32.

19 Frink EJ, Malan PT, Atlas $M$, et al. Clinical comparison of sevoflurane and isoflurane in healthy patients. Anesth Analg 1992; 74: 241-5.

20 Wellborn LG, Hannallah RS, Norden JM, Ruttiman $U E$, Callan CM. Comparison of emergence and 
recovery characteristics of sevoflurane, desflurane, and halothane in pediatric ambulatory patients. Anesth Analg 1996; 83: 917-20.

21 Jellish WS, Lien CA, Fontenot HJ, Hall R. The comparative effects of sevoflurane versus propofol in the induction and maintenance of anesthesia in adult patients. Anesth Analg 1995; 82: 479-85.

22 Smith I, Ding $\Upsilon$, White PF. Comparison of induction, maintenance and recovery characteristics of sevoflurane$\mathrm{N}_{2} \mathrm{O}$ and propofol-sevoflurane- $\mathrm{N}_{2} \mathrm{O}$ with propofolisoflurane- $\mathrm{N}_{2} \mathrm{O}$ anesthesia. Anesth Analg 1992; 74: 253-9.

23 Nathanson $M H$, Fredman B, Smith I, White $P$. Sevoflurane $v s$ desflurane for outpatient anesthesia: a comparison of maintenance and recovery profiles. Anesth Analg 1995; 81: 1186-90.

24 Apfelbaum JL, Grasela TH, Walawander CA, et al. Bypassing the PACU - a new paradigm in ambulatory surgery. Anesthesiology 1997; 87: A32.

25 Song $D$, White PF, Johnson ER. Does EEG-BIS monitoring facilitate fast-tracking after ambulatory anesthesia? Anesthesiology 1997; 87: A31.

26 Bell $S$, Hill $N$. Factors facilitating PACU bypass in ambulatory surgery. Anesthesiology 1997; 87: A34.

27 Twersky RS. Recovery and discharge of the ambulatory anesthesia patient. ASA Refresher Course \#412, 1997; San Diego, California.

28 McKenzie R, Lim Uy NT, Riley TJ, Hamilton DL. Droperidol/Ondansetron combination controls nausea and vomiting after tubal banding. Anesth Analg 1996; 83: 1218-22.

29 Steinbrook RA, Freiberger D, Gosnell JL, Brooks DC. Prophylactic antiemetics for laparoscopic cholecystectomy: ondansetron versus droperidol plus metoclopramide. Anesth Analg 1996; 83: 1081-3.

30 Cieslak GD, Watcha MF, Phillips MB, Pennant JH. The dose-response relation and cost effectiveness of granisetron for prophylaxis of pediatriac postoperative emesis. Anesthesiology 1996; 85: 1076-85.

31 Kovac AL, Scuderi PE, Boener TF, et al. Treatment of postoperative nausea and vomiting with a single intravenous doses of dolasetron mesylate: a multicenter trial. Anesth Analg 1997; 85: 546-52.

32 Watcha NF, Smith I. Issues in cost containment. Cost effectiveness analysis of antiemetic therapy for ambulatory surgery. J Clin Anaesth 1994; 6: 370-7. 


\section{Mise a jour en chirurgie ambulatoire}

$\mathrm{U}$ cours des 20 dernières années, le changement le plus dramatique dans la prestation de soins chirurgicaux aux États-Unis a été le déplacement des soins du secteur hospitalisé au secteur ambulatoire ou de court-séjour. La chirurgie ambulatoire des années 90 , avec la démonstration de ses efforts pour le contrôle des coûts, a été adoptée par tous les segments du système de santé américain. Par conséquent, la chirurgie ambulatoire représente actuellement $65 \%$ de toutes les procédures chirurgicales, alors que le secteur hospitalisé ne représente plus que 35\%. Peu de professionnels de la santé voudraient remettre en question le fait que la croissance continue de la chirurgie ambulatoire a eu un impact significatif sur la façon de pratiquer des chirurgiens et des anesthésistes. Cette présentation va mettre en relief les nouvcaux développements en anesthésie ambulatoire, incluant les possibilités pour le médecin périopératoire pratiquant l'anesthésie en bureau, les mécanismes de dépistage préopératoire, les examens de laboratoire, les choix d'agents anesthésiques optimaux et la prise en charge postopératoire.

\section{L'anesthésie en bureau}

Les progrès technologiques et les développements en anesthésie ont permis au nombre et à la complexité des procédures chirurgicales ambulatoires réalisées chaque année de croître et de ne plus être limitées au contexte hospitalier. Actuellement, les Centres de Chirurgie Ambulatoire (ASC = Ambulatory Surgery Centers) et la chirurgie réalisée au bureau représentent environ 12 et $8 \%$ respectivement de la part de marché de la chirurgie aux États-Unis. Les projections sont que les ASCs et les procédures réalisées au bureau vont augmenter à 17 et $1.4 \%$ respectivement d'ici à l'an 2001 (Figure 1) ${ }^{1}$. Cette croissance a été poussée par des motifs financiers. Néarnmoins, un haut niveau de satisfaction de la part des chirurgiens et des patients continue à attirer de plus en plus de procédures vers l'ambulatoire. Du côté des procédures réalisées au bureau, les plus fréquentes sont des procédures de plastie, de dermatologie, de chirurgie buccale et de gynécologie (Figure 2). Pour ces procédures, même s'il y a eu changement vers un site moins intensif, la pratique anesthésique doit respecter les mêmes critères de qualité que ceux qui s'appliquaient à l'hôpital ou dans les ASCs. Le rôle de l'anesthésiste pratiquant en bureau dépasse le simple fait d'administrer l'anesthésiel.
Rebecca S. Twersky, MD

Ses responsabilités supplémentaires peuvent inclure la nécessité de faire accréditer le bureau comme un site où l'anesthésie est administrée, la confirmation des aptitudes du chirurgien, la vérification de l'équipement de sécurité du bureau, la mise au point de protocoles d'urgence, l'évaluation appropriée des patients, la supervision du réveil des patients et la gestion des données concernant

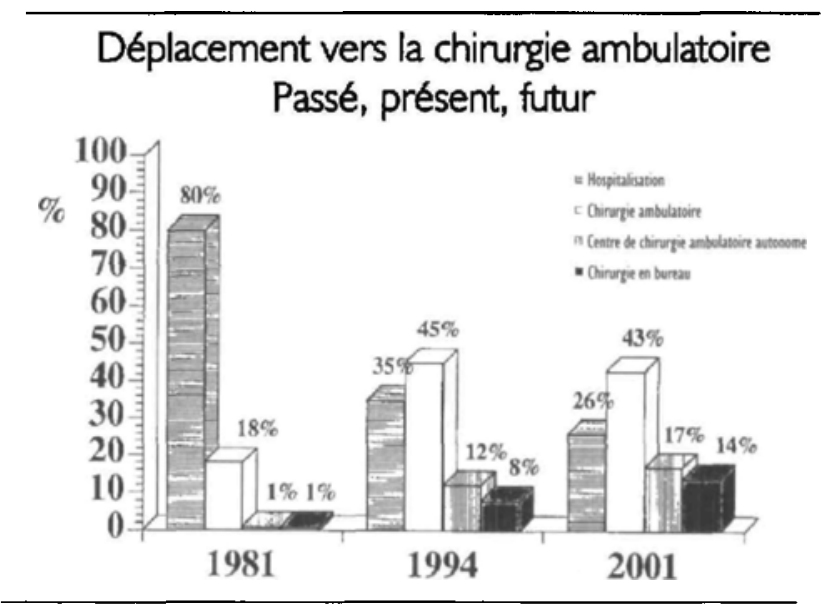

FIGURE I

\section{Procédures en bureau: selon les spécialités}

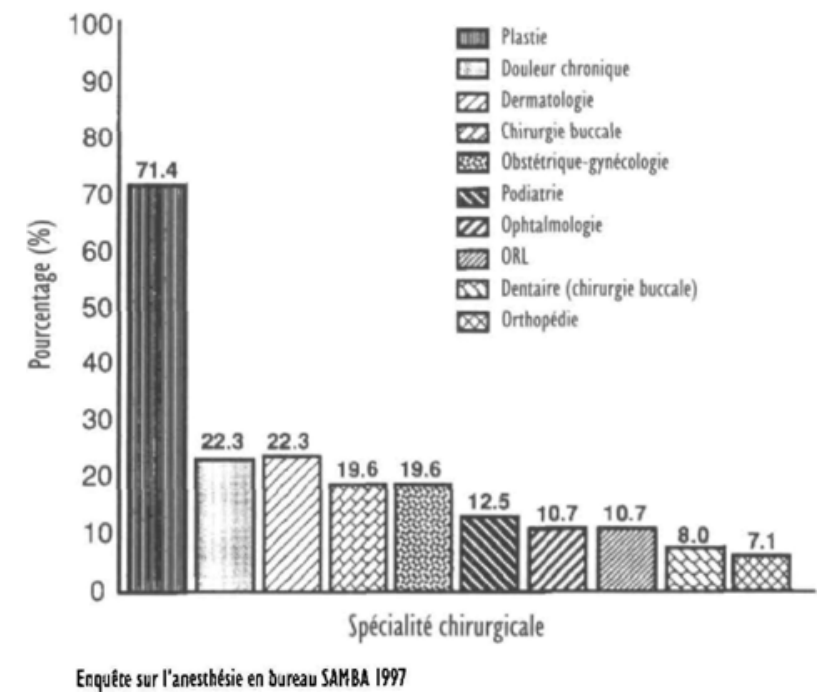

FIGURE 2 
TABLE I Anesthésie et chirurgie en bureau

\author{
Liste de vérification \\ 『 Conception des installations \\ ■ Équipement et fournitures \\ $\square$ Trafic des patients \\ ■ Entente pour transfert à l'hôpital \\ Ð Organisation d'urgence \\ \ MDs compétents et en règle \\ Évaluation de la qualité et revue par les pairs
}

l'amélioration de la qualité (Table 1). Les besoins de base de l'anesthésie en bureau doivent être conformes aux standards et au monitorage tels que définis par l'American Society of Anesthésiologists (ASA). L'anesthésiste qui pratique en bureau doit s'assurer que l'endroit est équipé pour permettre la ventilation à pression positive avec un Ambu et avec une source d'oxygène. La succion peut être assurée par un système fixe ou mobile; pour tout l'équipement anesthésique on doit pouvoir compter sur de l'équipement de rechange ainsi que sur une source électrique d'urgence en cas de défaut. Indépendamment des techniques anesthésiques utilisées, un équipement d'urgence pour le maintien des voies respiratoires, de même qu'un défibrillateur, sont des prérequis essentiels à la pratique en bureau. Alors que des ingénieurs biomédicaux et des techniciens sont facilement disponibles pour s'occuper de l'entretien et répondre aux pannes dans le contexte hospitalier et celui des ASCs, ce n'est pas la même situation en bureau. Il est donc essentiel que l'entretien de l'équipement, de même que les vérifications de routine, soient faits de façon rigoureuse et que tout le processus soit surveillé de près. De plus l'anesthésiste doit devenir familier avec la disposition des appareils et doit se sentir confortable dans leur utilisation. Dans le contexte du bureau, l'anesthésiste fait aussi office de pharmacie et de pharmacien: il doit done s'assurer d'avoir sous la main un éventail complet de médicaments, incluant ceux nécessaires à la réanimation d'un patient en arrêt cardiaque ou respiratoire, ainsi que le dantrolène pour le traitement d'une hyperthermie maligne. Si des substances contrôlées sont gardées au bureau, l'anesthésiste doit obtenir de la DEA (Drug Enforcement Agency) une licence pour les narcotiques.

La sélection des patients pour la pratique en bureau va continuer à évoluer en même temps que les développements anesthésiques et chirurgicaux. La classification selon l'état physique de l'ASA demeure un élément important de sélection des patients; cependant d'autres éléments sont moins clairs. Les limites d'âge et la morbidité associée à des états morbides spécifiques (par exemples la maladie cardiovasculaire, l'asthme, l'obésité morbide)devront être mieux définies. Comme pour les ASCs et les hôpitaux, une méthode efficace d'évaluation des patients pour le bureau devrait être en place. Une consultation téléphonique préopératoire réalisée par l'anesthésiste aidera à la sélection des patients. À mesure que cette forme de pratique gagnera en popularité, plus de données d'assurance de qualité vont devenir disponibles pour aider à la sélection des patients appropriés aux procédures réalisées en bureau.

\section{Cliniques d'anesthésie préopératoire}

Avec la proportion croissante de patients prévus pour une chirurgie ambulatoire ou en court-séjour dans toutes sortes d'environnements, un mécanisme pour des soins périopératoires sans à coup et sans faille est nécessaire. A date, les cliniques d'anesthésie préopératoire sont la façon la plus complète disponible pour combler ces besoins. L'anesthésiste, dans son rôle redéfini de spécialiste médical périopératoire, est le meilleur individu pour évaluer médicalement le patient et établir un plan de traitement périopératoire ${ }^{2}$. Ceci ne peut être délégué au médecin de première ligne. Les avantages qu'il y a à établir une clinique d'anesthésie préopératoire incluent une diminution des examens de laboratoire et des consultations superflues, une diminution des délais et des annulations des chirurgies, avec comme conséquence un accroissement de la satisfaction du chirurgien et du patient ${ }^{3}$. La clé du succès d'une clinique de préanesthésie réside dans la qualité de son personnel. L'anesthésiste, à titre de Directeur Médical, est en charge d'une évaluation complète des patients en collaboration avec des résidents d'anesthésie, d'autres médecins comme assistants, des infirmières cliniciennes ou des infirmières périopératoires. D'autre personnel clé inclut des éducateurs infirmiers, responsables des portions essentielles de l'enseignement préopératoire, le personnel de laboratoire, la radiologie et autres services de soutien, les préposés à l'admission, le personnel des archives et le gérant du bureau. La clinique préopératoire idéale est celle qui permet que tous les éléments nécessaires à l'évaluation préopératoire puissent être obtenus au cours d'une seule visite. Le concept du «tout sous le même toit» a été popularisé comme agent de promotion de soins efficaces, axés sur les besoins du patient. Le but est une clinique d'anesthésie préopératoire avec la capacité de réaliser l'évaluation requise en une seule visite, au moins pour la majorité des patients; elle doit done comporter des espaces pour l'enregistrement, être intégrée au système informatisé de l'établissement et posséder des salles d'examens où les patients peuvent être questionnés et examinés, les signes vitaux pris, les ECG réalisés et enfin les analyses prélevées. En outre, les services de radiologie devraient y être intégrés ou être disponibles et proches. Un équipement audiovisuel ou un endroit où est disponible la documentation pour l'enseignement aux 


\section{Algorythme d'évaluation préanesthésique}

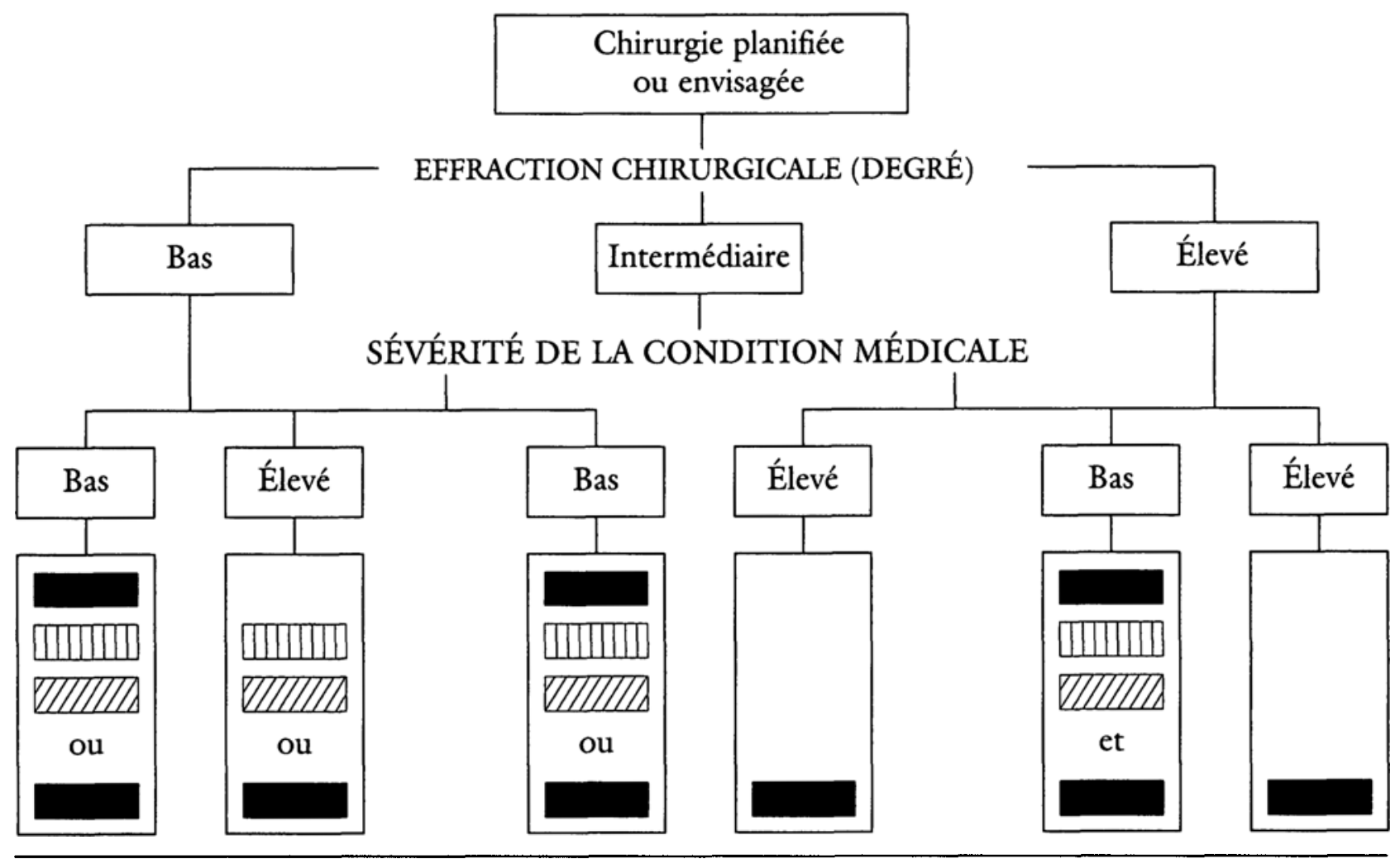

FIGURE 3 Algorythme d'évaluation préanesthésique

Model A: Informations concernant le patient provenant du chirurgien Revue par un anesthésiste avant/ou le jour de la chirurgie (JDC)

Uلس Model B: Informations concernant le patient provenant du médecin depremière ligne Revue par un anesthésiste avant/ou le JDC

Eutzo Model C: Informations provenant du chirurgien ou du médecin de première ligne. Relance téléphonique par l'anesthésiste avant le JDC

Model D: Informations provenant du chirurgien ou du médecin de première ligne.Évaluation par l'anesthésiste à une clinique d'anesthésie avant le JDC

patients peut favoriser l'enseignement préopératoire. Dépendant de la sévérité de la pathologie médicale du patient et de la chirurgie planifiée, d'autres options peuvent être envisagées pour satisfaire une unité chirurgicale en particulier (Figure 3). Une alternative de ce type consiste à faire remplir le questionnaire de santé au bureau du chirurgien ou du médecin de première ligne, lequel questionnaire est revu par l'anesthésiste avant l'administration de l'anesthésie. Cependant, le succès d'une telle option réside dans une ligne de communications très claire entre les anesthésistes, les chirurgiens et les médecins de première ligne quant à la définition d'un patient «stable». À cause du manque d'uniformité avec laquelle les collègues médecins évaluent les patients avant une opération, un document standard distribué à cet effet peut corriger le problème. Il faut cependant noter que ce document n'est pas un simple laisser-passer pour la chirurgie mais bien une vérification que le patient est dans son état optimal pour la chirurgie. La valeur des cliniques préanesthésiques devient très apparente lorsque des patients "problème» sont identifiés tôt dans le processus et que la prise de décision médicale appartient à l'anesthésiste 4 . Pour les patients qui sont en meilleure santé, un questionnaire téléphonique avant la chirurgie réalisé par un membre d'une équipe dirigée par l'anesthésie peut aider à mettre en route l'évaluation préanesthésique, identifier les candidats inapproprés et corriger l'information inexacte à propos des directives préopératoires. Les évaluations de santé informatisées et l'utilisation par les patients de l'Internet s'avéreront utiles dans le futur pour raffiner davantage le processus. L'efficacité clinique et administrative, de même que la visibilité qu'elle procure à l'anesthésiste, sont les facteurs majeurs de promotion des cliniques préanesthésiques. Par-dessus tout, les cliniques d'évaluation préopératoire doivent être adaptées à chaque pratique particulière et 
doivent être influencées par les mécanismes en place dans chaque établissement de même que par la complexité des patients.

L'utilisation d'examens de laboratoire inutiles a été un facteur contributif aux coûts excessifs de la santé. De multiples études ont conclu que les examens de laboratoire de dépistage démontrent peu fréquemment des anomalies et mènent rarement à des changements de conduite qui améliorent le résultat ${ }^{5}$. Par exemple, une méta analyse d'études de radiographies pulmonaires préopératoires prises sans indications spécifiques a montré que des faux positifs conduisant à des procédures invasives et à une morbidité associée étaient plus fréquents que la découverte d'éléments nouveaux entraînant un changement de traitement ${ }^{5}$. Il y a peu de raisons de faire des tests de dépistage chez des patients asymptomatiques et à faible risque. Des examens préopératoires ne devraient être réalisés que s'ils sont indiqués par l'histoire médicale ou l'examen physique, ou s'ils ont une influence sur les soins périopératoires (Table II).

\section{Sélection des patients}

En dépit des cliniques de dépistage les plus complètes et des autres méthodes d'évaluation, des patients présentant un défi médical vont continuer à se présenter en chirurgie ambulatoire élective. Les questions-clé à poser pour décider si un patient est approprić à un tel environnement sont: 1) Quelle est l'importance de la maladie du patient? 2) Quel est le statut fonctionnel du patient? 3) Le patient est-il optimal du point de vue médical? 4) Le patient doit-il être traité dans une unité séparée ou dans une unité ambulatoire intégrée à un hôpital? 5) Quels sont les risques à retourner ce patient à la maison le même jour? 6) Le patient serait-il mieux traité si hospitalisé? Au minimum, ces questions doivent être posées et il doit y avoir dialogue entre l'anesthésiste, le chirurgien et le médecin de première ligne. L'anesthésie et la chirurgie pour un tel patient peuvent être entreprises après solution des questions médicales, après conclusion que le patient est stable et que son environnement est adéquat pour le congé.

Malgré les progrès technologiques et les développements de l'anesthésie, certains types de patients présentent un risque en chirurgie ambulatoire et d'autres environnements devraient être envisagés (Table III). On retrouve dans cette catégorie les patients ASA 3 et 4 instables, les diabétiques instables, les alcooliques et narcomanes non contrôlés, les épileptiques mal contrôlés, les obèses morbides avec autre pathologie, ainsi que le patient susceptible à l'hyperthermie maligne (risque relatif). Plusieurs facteurs de risque ont été associés à une incidence accrue de problèmes cardiaques et respiratoires dans la période périopératoire en chirurgie
TABLE II Examens préanesthésiques: Recommandations concernant des individus asymptomatiques en bonne santé

\begin{tabular}{ll}
\hline - Pédiatrie & $\begin{array}{l}\text { Pas d'examen sauf si indiqué par } \\
\text { histoire/examen }\end{array}$ \\
$\begin{array}{ll}\text { Femmes } \\
\text { Âge reproductif: }\end{array}$ & Hb/Hte, test de grossesse \\
$50-64$ ans: & Hb/Hte, ECG \\
- Hommes & Pas d'examen sauf si indiqué par histoire/ \\
$<45$ ans & examen \\
& Hb/Hte, ECG \\
$45-64$ ans & Hb/Hte, ECG, BUN/Glucose \\
- Adultes $>65$ ans & Prescrits selon l'histoire/examen \\
\hline
\end{tabular}

TABLE III Patients adultes: statut ambulatoire inapproprié

- Patients ASA 3 et 4 instables du point de vue cardiaque, pulmonaire, rénal, endocrinien, cancer.

- Diabétiques instables

- Narcomanes/alcooliques actifs

- Difficultés psychosociales ??

- Épilepsie mal contrôlée

- Hyperthermie maligne \pm

- Obèses morbides \pm

- Apnée du sommeil

TABLE IV Ex-prématuré: risque d'apnée postopératoire

- Apnec de >15 sec ou moins si accompagnée de bradycardi Anémic (Hte $<30 \%$ )

- Risque $5 \%$ jusqu'à 48 semaines d'âge post conceptuel si né à 35 semaines

- Risque $5 \%$ jusqu'à 50 semaines d'âge post conceptuel si né à 32 semaines

- Risque < ou = à $1 \%$ à partir de 54 semaines d'âge post conceptuel si né à 35 semaines

- Risque $<$ ou $=\mathrm{d} 1 \%$ à partir de 56 semaines d'âge post conceptuel si né à 32 semaines

- Pas de risque accru pour le bébé petit pour l'âge gestationnel Côté et al: Anesthesiology 1995; 82: 802-22

ambulatoire ${ }^{7}$, et de ce fait les patients présentant ce type de risque doivent être évalués soigneusement quant au bien fondé de leur statut ambulatoire. La plupart des enfants sont en bonne santé et nécessitent une préparation préopératoire minime. L'évaluation préopératoire pédiatrique devrait inclure une histoire et un examen physique, incluant la médication, l'évaluation de la condition face à la chirurgie proposée, et les recommandations indiquées (par exemples: prophylaxie de l'endocardite, stéroïdes, etc.). Ceux qui présentent des maladies associées peuvent bénéficier de la chirurgie ambulatoire parce que la séparation parentale est plus brève et l'exposition aux infections nosocomiales plus courte. Cependant, comme avec la population adulte, 
certains patients pédiatriques inappropriés au contexte ambulatoire sont dirigés vers ce type de chirurgie; à titre d'exemple mentionnons les patients avec apnée du sommeil, les porteurs d'anémie falciforme et ceux susceptibles à l'hyperthermie maligne (risque relatif). À partir de quel âge un patient pédiatrique peut-il être traité en chirurgie ambulatoire? Des nourrissons en santé, nés à terme et âgés de 44 semaines post conception peuvent être traités en ambulatoire alors que pour des prématurés c'est inapproprié. Le risque d'apnée postopératoire chez d'anciens prématurés a exclu l'ancien prématuré de moins de 44 semaines d'âge post conceptuel de même que celui de plus de 60 semaines mais avec symptômes cardiopulmonaires persistants $\left(\right.$ Table IV) ${ }^{8}$. Des nourrissons en santé, nés à terme, et âgés de 44 semaines peuvent subir une chirurgie élective en ambulatoire.

\section{Les nouveaux agents anesthésiques pour l'ambulatoire}

Quel est l'agent anesthésique idéal pour le patient ambulatoire? Cet agent devrait s'administrer de façon simple et sécuritaire, avec un début d'action rapide, un arrêt rapide, des effets secondaires postopératoires minimes et une analgésie résiduelle durant la période postopératoire initiale. Le développement d'agents anesthésiques intraveineux (remifentanil, propofol) et d'inhalation (desflurane, sevoflurane) démontrant des propriétés de début rapide et de récupération rapide souhaitables en chirurgie ambulatoire a eu un impact positif sur la pratique de l'anesthésie ambulatoire. Depuis sa mise au point à la fin des années 80 , le propofol a conservé son rôle comme le principal agent pour l'induction et le maintien de l'anesthésie générale, de même que la sédation, dans le contexte ambulatoire. En raison de son profil de récupération unique parmi les autres agents anesthésiques $i v$, le propofol est considéré comme l'agent sédatif-hypnotique d'induction et de maintien de choix pour l'anesthésie ambulatoire'. Les propriétés de clairance métabolique extrêmement rapides du propofol facilitent un réveil rapide du patient et un retour rapide à un sensorium clair.

Le remifentanil est l'un des plus récents agents anesthésiques intraveineux. C'est un opiacé puissant ultra-court, avec un début d'action extrêmement rapide (les taux sériques sont atteints en 2 à 3 minutes). Le médicament est hydrolysé par les estérases plasmatiques, la demi-vie beta est d'approximativement de 6 à 10 minutes et les produits de dégradation sont inactifs ${ }^{11-12}$. Ainsi, le médicament peut être administré par infusion pour un maintien optimal sans crainte d'accumulation dans le sang. Toutefois, une conséquence de cette caractéristique est que les patients peuvent ressentir de la douleur plus précocement et qu'une analgésie de transition (par exemples: kétorolac, anesthésiques locaux longue action) doit être débutée en SOP pour fournir une analgésie dans le postopératoire immédiat ${ }^{12}$. Un bénéfice de ce besoin d'analgésie de transition est de forcer l'anesthésiste à s'intéresser à la stratégie d'analgésie postopératoire pendant qu'il est en SOP. L'utilisation de remifentanil en ambulatoire est particulièrement bénéfique pour les patients avec maladies cardiaques qui nécessitent une analgésie par opiacés intense en peropératoire sans narcose résiduelle. Une autre qualité du remifentanil pourrait être une incidence plus faible de vomissements provoqués par les opiacés ${ }^{13}$.

Le desflurane et le sevoflurane sont les plus récents agents d'inhalation, mis sur le marché aux États-Unis en 1993 et en 1995. Le desflurane, à la température de la pièce, est un liquide clair, ininflammable, avec une odeur forte. C'est un méthyl-éthyl éther fluoré, identique à l'isoflurane en termes de structure sauf pour le remplacement par un fluor du chlore situé sur le carbone alpha-éthyl. C'est le moins soluble et le moins puissant des agents d'inhalation avec un coefficient de partition sang-gaz de 0,42 et une CAM de 6,0 $\pm 0,09$ chez l'adulte âgé de 30 à 60 ans. La pression de vapeur élevée du desflurane requiert un vaporisateur spécial, le TEC 6, pour fournir un contrôle de température adéquat et une précision du débit à tous les réglages. Malheureusement, des problèmes de conception ont affecté le système TEC 6 depuis sa création, entraînant des délais substantiels dans l'acceptation initiale du desflurane par la FDA et, plus récemment, un rappel massif des vaporisateurs à cause d'un problème de débit inexact lorsque des concentrations élevées de desflurane étaient utilisées avec des débits élevés de gaz. Le problème de calibration du vaporisateur semble maintenant résolu. Récemment, le rôle du desflurane dans la production de monoxyde de carbone $(\mathrm{CO})$ dans les absorbeurs de $\mathrm{CO}_{2}$ a été étudié. On a montré que le desflurane peut produire 2000 PPM de CO, et qu'il peut produire 15 fois plus de $\mathrm{CO}$ que l'isoflurane si la température est élevée $\left(45^{\circ} \mathrm{C}\right)$ et si l'absorbeur est sec (spécialement les absorbeurs utilisant l'hydroxyde de baryum) ${ }^{14}$. Le Center for Disease Control de la FDA a émis les recommandations suivantes concernant l'intoxication au $\mathrm{CO}$ durant l'anesthésie: 1) toute chaux sodée qui demeure inutilisée pour plus de 24 heures dans la machine d'anesthésie doit être changée et la date apposée 2) la machine d'anesthésie doit être rincée avec un flot continu de $100 \% \mathrm{O}_{2}$ durant au moins 1 minute avant le premier cas du jour.

Les effets cardiovasculaires du desflurane sont semblables à ceux de l'isoflurane. Une activation transitoire du système nerveux sympathique, entrainant une tachy- 
cardie et une hypertension, se produit en relation avec la concentration de desflurane et avec la rapidité de variation de cette dernière. Les opiacés, le propofol ou la clonidine par voie iv peuvent atténuer cette réponse. Le desflurane doit être utilisé avec précaution pour induire l'anesthésie parce que des hautes concentrations causent de l'irritation des voies respiratoires, ce qui entraine de la toux, de la salivation excessive, du laryngospasme et de l'apnée. Le desflurane est nettement plus approprié comme agent de maintien dans le contexte amublatoire. Des études récentes ont montré que le desflurane permet un réveil initial plus rapide que le propofol lorsque les deux ont été utilisés depuis l'induction. Cependant, le réveil plus complet et le congé s'effectuaient dans les mêmes temps pour les deux agents ${ }^{15}$.

Le sevoflurane, à la température de la pièce, est un liquide clair, ininflammable avec peu d'odeur, ou une odeur non irritante. C'est un éther méthyl-isopropyl avec une CAM de $2,93 \%$ chez l'adulte et un coefficient de partition sang/gaz de $0,6-0,7$, proche de celui du $\mathrm{N}_{2} \mathrm{O}$ et le rendant très approprié à l'anesthésie ambulatoire. Les changements cardiovasculaires sont moindre avec le sevoflurane qu'avec le desflurane, avec aucune activation apparente du système nerveux sympathique. Le sevoflurane semble instable dans les conditions in vitro et in vivo. La dégradation in vitro implique une réaction du sevoflurane avec l'absorbeur de $\mathrm{CO}_{2}$, produisant plusieurs composés appelés $\mathrm{A}, \mathrm{B}, \mathrm{C}, \mathrm{D}$. Même si dans certaines conditions cliniques tous ces composés peuvent être formés, les quantités de composé $\mathrm{B}, \mathrm{C}$ et $\mathrm{D}$ semblent négligeables $(<0,5 \mathrm{ppm})$ et ne sont en général formées que lorsque la température de l'absorbeur est élevée (environ $46^{\circ} \mathrm{C}$ ). Le composé $\mathrm{A}$ a généré le plus d'inquiétudes à cause de sa toxicité rénale chez différents modèles animaux. La toxicité du composé A chez le rat est bien documentée et représente principalement une toxicité corticomédullaire (aux environs de 100-300 ppm) induisant une acidose tubulaire rénale. Cependant, en dépit d'études cliniques extensives, plusieurs études n'ont pu démontrer aucune dysfonction hépatique ou rénale chez l'humain, même à des flots de gaz frais très bas ${ }^{16-17}$. Lorsque administré selon les recommandations du fabricant, les chances de toxicité humaine à long terme de l'exposition au sevoflurane semblent très faibles, même quand le sevoflurane est administré de façon prolongée.

L'induction en une seule respiration avec le sevoflurane permet une induction rapide et entraine un réveil doux et agréable ${ }^{18}$. Par comparaison avec l'isoflurane, le réveil, l'extubation et la capacité de répondre aux ordres est au moins aussi rapide ${ }^{19}$. Plusieurs études chez l'enfant ont montré que lors d'induction par inhalation avec le sevoflurane, l'halothane, ou le desflurane, c'est le sevoflurane qui permet les inductions les plus rapides ${ }^{20}$ et qui permet les réveils les plus rapides ou équivalents aux autres. Comparativement au propofol, le sevoflurane a démontré un réveil et une orientation plus rapides ${ }^{21-22}$.

En résumé, le sevoflurane et le desflurane procurent tous deux un meilleur contrôle de la profondeur anesthésique et un réveil initial plus rapide que ce qui est possible avec les autres agents d'inhalation ${ }^{23}$.

\section{Le réveil à trajectoire rapide}

Lorsqu'on les compare aux autres hypnotiques et agents d'inhalation, le sevoflurane, le desflurane, le propofol et le remifentanil possèdent des profils de réveil immédiat supérieurs; cependant, ces différences ne semblent pas persister dans la phase plus tardive du réveil. Il ne semble pas y avoir de différence significative entre le desflurane, le sevoflurane, le propofol et le remifentanil en ce qui concerne l'état prêt pour le départ ou le moment du congé de l'unité de chirurgie ambulatoire. Donc, pour démontrer les avantages potentiels de ces nouveaux composés plus coûteux, des modifications sont requises aux critères de congé du réveil et de l'unité ambulatoire. Si les patients de chirurgie ambulatoire sont éveillés et orientés dans la SOP, leur transfert directement à l'unité, évitant ainsi le réveil (procédure appelée «fast tracking = trajectoire rapide») va permettre un congé plus précoce. Les critères pour un réveil selon la «trajectoire rapide» sont: un patient éveillé et orienté sur la table d'opération, avec signes vitaux stables, avec saignement ou douleur minimes, sans nausées/vomissements importants, avec renversement complet du bloc neuromusculaire et avec saturation d'oxygène à $294 \%$ à l'air libre ou un retour à la saturation préopératoire. $\mathrm{Si}$ ces conditions sont satisfaisantes, le patient peut éviter la salle de réveil et être transféré directement à l'unité de réveil de niveau II, dans la mesure où il reçoit les soins appropriés. De façon à vraiment réussir la "trajectoire rapide», une méthode plus efficace de titration des agents anesthésiques pour déterminer la quantité nécessaire pour maintenir l'anesthésie est essentielle. Ce besoin a été comblé par le moniteur d'EEG Bis (Bispectral Array) produit par la compagnie Aspect. À la différence des autres moniteurs d'EEG pour la salle d'opération, le moniteur BIS affiche un paramètre continu pour l'évaluation de la profondeur de l'anesthésie, le BIS ou index bispectral. Les bénéfices de l'index bispectral incluent la capacité de mesurer l'état d'hypnose avec une très bonne corrélation avec les niveaux de médicaments hypnotiques, la possibilité de titrer plus précisément les agents anesthésiques, la 
détermination d'un point de vue neurologique du moment approprié pour l'extubation et la capacité de suivre le processus de réveil du patient. L'utilisation du moniteur BIS pour surveiller les anesthésies générales et les sédations profondes monitorées a entraîné une diminution significative de la quantité d'agent anesthésique administré ${ }^{25}$. L'utilisation de moniteur BIS pour déterminer la dose de propofol ou la concentration d'agents d'inhalation, l'élimination des prémédications et des opiacés se traduira en bénéfices sous forme de réduction des nausées/vomissements, d'ambulation plus précoce, de satisfaction accrue du patient, et de réveil et de congé rapides de l'environnement ambulatoire ${ }^{26}$. Les patients peuvent recevoir leur congé pour la maison lorsque les signes vitaux sont stables, lorsqu'ils peuvent marcher sans être étourdis, avec peu de douleur, peu de nausée/vomissement, peu de saignement et qu'une personne responsable peut les accompagner ${ }^{27}$.

\section{Douleur et vomissements postopératoires}

Deux des problèmes les plus fréquents rencontrés en chirurgie ambulatoire sont la douleur et les nausées/vomissements. Les opiacés (fentanyl, démérol, morphine) demeurent la méthode la plus utilisée et la plus efficace de traitement de la douleur aiguë postopératoire de modérée à sévère. À cause des symptômes indésirables que représentent les nausées/vomissements après utilisation d'opiacés, les anti-inflammatoires nonstéroïdiens (AINS) ou les anesthésiques locaux de longue durée devraient être envisagés comme composantes d'un traitement analgésique multimode. Les avantages des AINS par rapport aux opiacés sont: l'absence de dépression respiratoire, l'absence de dépression de la motilité intestinale, et la plus longue durée d'action. Il faut faire attention aux patients présentant des risques de saignement, d'atteinte de la fonction rénale ou de maladie bronchospastique. Pour la douleur légère à modérée, une médication orale, habituellement une combinaison d'opiacés et de non opiacés (par exemples: acétaminophène et codéine, acétaminophène et hydrocodone s'avère efficace (Table V) ${ }^{27}$.

Un problème probablement aussi ennuyeux que la douleur postopératoire est la survenue de nausées/ vomissements postopératoires (NVPO). Une thérapie antiémétique prophylactique doit être envisagée pour les patients les plus susceptibles (patients avec histoire antérieure de nausées/vomissements ou de mal des transports, patientes en phase lutéale du cycle menstruel). Le type d'intervention influence aussi les NVPO: de façon plus spécifique, la chirurgie du strabisme, la laparoscopic, la chirurgie de l'oreille moyenne et l'orchidopexie sont tous associées à une incidence relativement élevée de NVPO. Plusieurs agents anesthésiques, dont le $\mathrm{N}_{2} \mathrm{O}$,
TABLE V Médicaments analgésiques usuels et dosages

\begin{tabular}{llll}
\hline Médicament & $\begin{array}{l}\text { Voie } \\
\text { d'administration }\end{array}$ & Dose & $\begin{array}{l}\text { Durée } \\
\text { d'action (h) }\end{array}$ \\
\hline Acétaminiphène & $\mathrm{pr} / \mathrm{po}$ & $25-40 \mathrm{mg} \cdot \mathrm{kg}^{-1}$ & $4-6$ \\
Kétorolac & $i m / i \mathrm{iv}$ ? & $1 \mathrm{mg} \cdot \mathrm{kg}^{-1}(\mathrm{max} 30 \mathrm{mg})$ & $6-8$ \\
& $p o$ & $1 \mathrm{mg} \cdot \mathrm{kg}^{-1}(\mathrm{max} 10 \mathrm{mg})$ & $4-6$ \\
Ibuprofene & $p o$ & $5 \mathrm{mg} \cdot \mathrm{kg}^{-1}$ & $6-8$ \\
Codéine & $p o$ & $0,5-1 \mathrm{mg} \cdot \mathrm{kg}^{-1}$ & $4-6$ \\
Naproxen & $p o$ & $10 \mathrm{mg} \cdot \mathrm{kg}^{-1}$ & $6-8$ \\
Fentanyl & $i v$ & $1-2 \mu \mathrm{kg}^{-1}$ & $0.5-1$ \\
Mépéridine & $i v / i m$ & $0,5-1 \mathrm{mg} \cdot \mathrm{kg}^{-1}$ & $2-4$ \\
Morphine & $i v$ & $0,05-0,1 \mathrm{mg}^{-1} \cdot \mathrm{kg}^{-1}$ & $2-4$ \\
\hline
\end{tabular}

TABLE VI Traitements efficaces des NVPO en ambulatoire

\begin{tabular}{ll}
\hline - Dropéridol & $0,625-1,25 \mathrm{mg} i v$ \\
- Ondansétron & $4 \mathrm{mg} i v$ \\
- Ondansétron + Dropéridol & $4 \mathrm{mg} / 1,25 \mathrm{mg}$ iv \\
- Déxaméthazone & $150 \mu \mathrm{kg}^{-1} \mathrm{ad} 8 \mathrm{mg}$ \\
- Propofol? & $10 \mathrm{mg} \mathrm{iv}$ \\
- Antagonistes $5 \mathrm{HT} 3$ plus récents & \\
\hline
\end{tabular}

ont été associés avec une aggravation des NVPO; cependant des études plus récentes ont été incapables de démontrer une telle relation. Malgré une amélioration significative dans le traitement pharmacologique des NVPO, aucun traitement unique n'est complètement efficace. Cependant, une approche multimode s'est avérée efficace, cette efficacité atteignant $92 \%$ avec une combinaison de dropéridol et d'ondansétron ${ }^{28}$ (Table VI). Les antagonistes de la sérotonine, le plus nouveau groupe d'antiémétiques (ondansétron, granisétron, dolasétron), se sont montrés efficaces dans le traitement des NVPO, mais leur coût est très significatif ${ }^{29-31}$. C'est pourquoi, dans le climat actuel de contrôle des coûts, leur utilisation de façon prophylactique est impossible. Watcha et al. ${ }^{32}$, dans une analyse coût-bénéfice de la thérapie antiémétique en chirurgie ambulatoire, ont conclu que l'utilisation du dropéridol était plus acceptable que celle de l'ondansétron.

\section{Conclusion}

La chirurgie ambulatoire représente aujourd'hui un nouveau défi pour l'anesthésiste dans la mesure où l'accent s'est déplacé vers la ligne du bas: des soins de qualité et un contrôle des coûts. L'anesthésiste comme médecin périopératoire peut utiliser la plupart des leçons apprises dans le contexte de la chirurgie ambulatoire hospitalière et les appliquer à tous les environnements pour maintenir une anesthésie de haute qualité avec des résultats favorables.

\section{Références \\ (Voir page R82)}

